\title{
EFL Teachers' Knowledge toward Their Current Practices
}

\author{
Darmawati Saleh*, Sanitah Bte Mohd Yusof \\ Faculty Education, University Technology Malaysia, Johor Bahru, Malaysia
}

\section{Email address:}

darmawati_saleh@yahoo.com (D. Saleh), p-sanitah@utm.my (S. B. M. Yusof)

\section{To cite this article:}

Darmawati Saleh, Sanitah Bte Mohd Yusof. EFL Teachers' Knowledge toward Their Current Practices. International Journal of Secondary Education. Vol. 3, No. 4, 2015, pp. 37-42. doi: 10.11648/j.ijsedu.20150304.13

\begin{abstract}
There are many factors which influence the process of teaching English as a foreign language. One of the most influential in the process of teaching English is teachers' knowledge of teaching English. Knowledge of teaching English plays an important role in teachers' effectiveness and their choice of instructional practices. The total sampling of 133 Indonesian EFL teachers with different years of teaching experiences were participated in this study. After obtaining the raw data, the SPSS software (version 20) was used to analyze the data. The findings showed that the most dominant element of EFL teachers' knowledge of teaching English is teaching skills, and there is a significant influence of EFL teachers' teaching skills to their practices of teaching English. This research also indicated that there are no significant differences among the years of EFL teachers' teaching experiences toward their knowledge of teaching English.
\end{abstract}

Keywords: Knowledge of Teaching English, Teaching Experiences, EFL Teachers

\section{Introduction}

Today, there are a lot of studies indicate that teachers' knowledge have the most significant effect on students' achievement and success $[1,2,3,4]$. However, very few have been conducted to study teachers' knowledge in the teaching of English as a foreign language.

The profession of teaching is not an easy task. Teaching profession requires specific knowledge and skills $[5,6]$. Effective teachers must have broad knowledge and pedagogical skills to be able to face challenges in school [7], to determine the teachers' success in teaching [8], to teach appropriately and efficiently to encourage appropriate behavior [9], and in adopting innovative and effective teaching and learning process [10].

The effectiveness of teaching, as cited in [11] depends on teachers' understanding of the context of teaching, the needs of teachers and learners, the careful lesson planning and materials as well as the monitoring of teaching and learning. Moreover, to be effective, teachers must understand and able to apply the knowledge to help students increase their motivation and achievement [12]. An effective teacher utilizes education and experience to make choices on what to teach, how to teach, and how to endorse a good environment to sustain student learning [13].

Teachers' teaching experiences also may affect the design of lesson plans and the selection of class materials and activities. Moreover, experienced teachers were found to have a well-organized knowledge base [14]. This means that teachers' teaching experiences may affect teachers' knowledge of teaching English.

Given significant role of teachers' knowledge in the effectiveness of teaching, there is a need to understand comprehensively the knowledge of teaching English which may affect the process of teaching English as a foreign language. This study attempts to investigate EFL teachers' knowledge of teaching English in secondary schools in Indonesia and its relationship on their years of teaching experiences and their practices of teaching English.

Due to the importance of these factors to help improve the quality of EFL teaching in secondary schools, this study addressed the following research questions:

1) What is the most dominant element of EFL teachers' knowledge of teaching English?

2) What is the influence of the most dominant element of EFL teachers' knowledge of teaching English to their practices of teaching English?

3) Are there any significant differences among the years of EFL teachers teaching experiences toward their knowledge of teaching English? 


\section{EFL Teachers' Knowledge of Teaching English}

\subsection{The Elements of Knowledge of Teaching English}

According to [15], the concept of teaching is closely related with the concept of learning. This concept implies that teaching is relevant to teach students how to learn. [16] also defined the teaching as a specified set of effective teaching practices and competencies that these can be taught and tested and that their application is adequate to create good second language teaching. He recognizes some elements of content and knowledge base as representing the knowledge base of second language teacher. These elements are interrelated, inadequate of one skill or element may lead to inadequate access to other element. The following elements are:

\subsubsection{Teaching Skills}

Teaching skills would be the core competency of an English teacher. [8] terms the teaching skills as instruction that refers to those teaching aspects. Teaching skills involves selecting learning activities, presenting language, ensuring students' understanding, organization and facilitation communication interaction, judgment of proper balance between fluency and accuracy, awareness of students' errors and proper treatment of errors $[16,8,17]$.

\subsubsection{Subject Matter Knowledge}

In relation to English language teaching, subject matter knowledge is the specific concepts, theories and disciplinary knowledge that constitute the theoretical basis for the field of second language teaching, in which that second language teachers need to know about their subject [16].

\subsubsection{Pedagogical Reasoning \& Decision Making}

Some researchers refer to pedagogical reasoning and decision making as the cognitive skills that underlie teaching actions and processes [8, 18, 19]. [8] further argued that comprehension alone is not enough. Only the teachers who understand the teaching context can teach. Teachers must use their understanding or knowledge base for judgment (or choices) and action.

\subsubsection{Contextual Knowledge}

Contextual knowledge refers to the understanding of the specific context include knowledge of the school setting, knowledge of students' background, families, weaknesses, particular strengths and interests [20,21]. Understanding the context in which the practice of teaching takes place is an important element of an English teachers' knowledge.

\subsubsection{Communication Skills}

Communication skills are the fundamental skills of a good teacher to achieve the interpersonal goals successfully during an encounter, such as: (1) ordering, requesting, and giving rule, (2) questioning, (3) giving instruction, (4) repeating \& reporting what has been said, (5) warning \& giving advice, (6) giving reasons \& explain, and (7) giving \& refusing permission $[22,11]$.

\subsection{The Role of Teaching Experiences}

[23] stated that teachers who teach less than three years are ineffective, while they steadily improved at around five years. Moreover, [24] argued that unlike the less experienced or novice teachers, experienced teachers found to own a well-organized knowledge base about their students \& the classroom environment that enable them to differentiate, simplify, and transform the information in the learning process, and also to create alternative choices without frustrating the students.

In addition, [25] found that novice or beginning teachers usually have the following characteristics: (1) novice teachers are less able to choose the important information when designing the lesson; (2) they lack of vocabulary to analyze and discuss the teaching; (3) they lack of knowledge of students on how to deal with students' difficulties, and improving students' motivation in learning; (4) they lack of pedagogical content knowledge; and (5) they are more focus to work from text book rather than improving students' achievement.

\subsection{The Teaching of EFL in Indonesia}

In Indonesia, although English is not used as a medium of communication in official domains, its teaching becomes increasingly important. English is officially a foreign language but offered as a compulsory subject taught for four periods in a week [26]. Recently, the government is contemplating to reduce the English teaching period. There is an indication that the teaching of English will be officially taught for two periods in a week, and it will be an elective subject in secondary schools and extracurricular subject in elementary schools [27].

The School Based English Curriculum adopts communicative competence as its model of competence [28]. The general standard objectives of the recent English School-Based Curriculum are: (1) to develop both oral and written communicative competence for informational literacy; (2) to raise awareness among citizenry in English as a foreign language in order to compete in global community; and (3) to develop learners comprehension in relation to language and culture [29] (Depdiknas RI, 2006).

Since English was initially taught, the teaching of English in lots of areas and schools, specifically in remote areas has not produce acceptable results. English instruction has been considered less of success in this country. Despite of many years of English teaching in formal schooling the result has not been satisfying. Actually, only small amounts of senior high school are able to communicate intelligibly in English $[30,31,32,33,34,35]$.

In the development of English language teaching in Indonesia, there are a lot of factors which cause the lack of the quality of English teaching [27, 36, 37, 34, 30, 38, 39] although the government has proposed the teacher qualification, Ministry of National Education [40] found that more than sixty percent of the total 2.78 million teachers did not hold undergraduate degrees in education [7]. Indonesian 
teachers are not highly qualified, lack of knowledge and inadequate qualification within specific field that is supposed to be their capital employment [41]. Many teachers are not competent in teaching English because of lack of qualification and proficiency in English.

\section{Methodology}

\subsection{Population and Sample}

The population of this research is EFL teachers who teach in secondary schools in South Sulawesi Province, Indonesia. The respondents from the survey were drawn from 50 secondary high schools in city and rural areas. The total sampling of 133 EFL teachers (Bachelor: 114 EFL teachers and Master: 19 EFL teachers) with different years of teaching experiences were participated in this study. In Indonesia, five years of teaching experiences is the cut point for dividing the less experienced teacher and the experienced teacher. Teaching experiences will be categorized into three groups, these groups are the representative of the less experienced EFL teachers (1-4 years), the experienced EFL teachers (5-10 years) and the most experienced EFL teachers (above 10 years).

\subsection{Instrument}

The questionnaire survey of teachers' knowledge of teaching English was designed by [41]. It is used as an observation for EFL teachers' teaching by the teachers or themselves to determine their own teaching [11]. The researcher adapted the questionnaire to identify EFL teachers' knowledge of teaching English as self-report instead of observation. There are 24 items in this questionnaire, the items are rated on a 5-likert scale (1=Totally irrelevant, $2=$ Slightly important, 3=Important, 4=Very important, 5=Absolutely essential). Principal component factor analysis with varimax rotation was conducted, respectively on teaching skills (8 items), subject matter knowledge (4 items), pedagogical reasoning $\&$ decision making (4 items) and communication skills (4 items). The reliability was estimated using Cronbach's Alpha .86

The questionnaires survey of teaching practices was adapted from questionnaires survey on Chinese EFL Teachers perceptions of the College English Curriculum \& Its Implementation (Wang, 2006). There are 26 items in this questionnaires, the items are rated on a 5-likert scale $(1=$ strongly disagree, $2=$ disagree, $3=$ neutral (neither agree nor disagree), 4=agree, 5=strongly agree). Principal component factor analysis with varimax rotation indicated those 13 items for planning and 13 items for implementation. The reliability was estimated using Cronbach's alpha .84.

\subsection{Procedure}

Survey questionnaires were distributing to the EFL teachers in their schools. Collecting the data started on February 2015 and lasted for about 3 months. The responses obtained from the questionnaires were tabulated and analyzed using SPSS software (version 20). Then, the mean and the standard deviation of items questionnaires were calculated to determine the most dominant element of EFL teachers' knowledge of teaching English and simple linear regression was employed to determine the influence of the most dominant element of EFL teachers knowledge of teaching English to their practices of teaching English. ANOVA was employed to determine the significance differences among the years of EFL teachers' teaching experiences and their knowledge of teaching English.

\section{Findings}

Table (1) presents the mean and the standard deviation of EFL teachers' knowledge of teaching English. Overall, teaching skills is the highest mean score (mean $=3.90, \mathrm{SD}=$ 0.55 ) compared with other elements such as subject matter knowledge $($ mean $=3.70, \mathrm{SD}=0.60)$, pedagogical reasoning $\&$ decision making $($ mean $=3.34, \mathrm{SD}=0.53)$, contextual knowledge $($ mean $=3.43, \mathrm{SD}=0.53)$ and communication skills (mean $=3.63, \mathrm{SD}=0.49$ ). This result revealed that the influence of EFL teachers' teaching skills on their knowledge of teaching English were at the high level.

Table 1. Mean and Standard Deviation of EFL Teachers' Knowledge of Teaching English.

\begin{tabular}{llll}
\hline No. & Knowledge of Teaching English & Mean & SD \\
\hline 1 & Teaching Skills & 3.90 & 0.55 \\
2 & Subject Matter Knowledge & 3.70 & 0.60 \\
3 & Pedagogical Reasoning \& Decision Making & 3.34 & 0.53 \\
4 & Contextual Knowledge & 3.43 & 0.53 \\
5 & Communication Skills & 3.63 & 0.49 \\
Total & & 3.65 & 0.41 \\
\hline
\end{tabular}

Table (2) showed the mean and the standard deviation of EFL teachers' practices of teaching English. Overall, the mean score of EFL teachers' practices of teaching English is 3.66 $(\mathrm{SD}=0.39)$. For planning, the mean score is $4.04(\mathrm{SD}=0.22)$, and for the implementation, the mean score is 3.46 ( $\mathrm{SD}=$ 0.32). As it can be observed, the EFL teachers performed equally well on planning than implementation.

Table 2. Mean and Standard Deviation of EFL teachers' Practices of Teaching English.

\begin{tabular}{llll}
\hline No. & Teaching Practices & Mean & SD \\
\hline 1 & Planning & 4.04 & 0.22 \\
2 & Implementation & 3.46 & 0.32 \\
Total & & 3.66 & 0.39 \\
\hline
\end{tabular}

Simple linear regression was used to examine the influence of the most dominant element of EFL teachers' knowledge of teaching English (teaching skills) to their practices of teaching English. Table (3) shows a simple linear regression analysis to predict the practices of teaching English. As shown, the correlation value $(R=.639)$ of the relationship between the two variables indicated that there is a high correlation between EFL teachers' teaching skills and their practices of teaching English. Whilst $\left(\mathrm{R}^{2}=.408\right)$ indicated that teaching skills contribute to $40.8 \%$ variance in the practices of teaching English. In other words, $59.2 \%$ of the variance in the practices of teaching English was left unaccounted for. 
Table 3. Regression Model the Practices of Teaching English-Teaching Skills.

\begin{tabular}{ll}
\hline Regression Statistic & \\
\hline $\mathrm{R}$ & .639 \\
$\mathrm{R}^{2}$ & 408 \\
Adjusted $\mathrm{R}^{2}$ & .403 \\
Error Standard of the Estimate & .30216 \\
\hline
\end{tabular}

$\mathrm{N}=133$
Furthermore, ANOVA analysis (Table 4) shows that there is a significant influence of EFL teachers' teaching skills to their practices of teaching English. As shown, the significant with the value of $\mathrm{F}(1,131)=90.210, \mathrm{p}=.000$.

Table 4. Regression Model of ANOVA Analysis the Practices of Teaching English - Teaching Skills.

\begin{tabular}{lllll}
\hline & Sum of Squares & Df & Mean Square & F \\
\hline Regression & 8.236 & 1 & 8.236 & 90.210 \\
Residual & 11.960 & 131 & .091 & $.000^{\mathrm{b}}$ \\
Total & 20.197 & 132 & & \\
\hline
\end{tabular}

Table (5) also shows the value of simple linear regression coefficients, B for the constant and teaching skill. Therefore, the regression equation to predict the score of the practices of teaching English can be written as follows:

$$
\mathrm{Y}=1.896+0.453 \mathrm{X}_{1}
$$

The constant of 1.896 indicates that if there is no activity of EFL teachers' teaching skills $(\mathrm{X} 1=0)$ then EFL teachers' practices of teaching English are 1.896.

Table 5. Regression Coefficient the Practices of Teaching English-Teaching Skills.

\begin{tabular}{|c|c|c|c|c|c|}
\hline & \multicolumn{2}{|c|}{ Unstandardized Coefficients } & \multirow{2}{*}{$\begin{array}{l}\text { Standardized Coefficients } \\
\text { Beta }\end{array}$} & \multirow{2}{*}{$\mathbf{T}$} & \multirow{2}{*}{ Sig. } \\
\hline & B & Std. Error & & & \\
\hline (Constant) & 1.896 & .188 & & 10.095 & .000 \\
\hline Teaching Skill & .453 & .048 & 639 & 9.498 & .000 \\
\hline
\end{tabular}

Moreover, Table (6) showed ANOVA procedure to determine the role of the years of EFL teachers' teaching experiences toward their knowledge of teaching English. Results of the ANOVA procedure revealed that there is no significant relationship between the years of EFL teachers' teaching experiences and their knowledge of teaching English $\mathrm{F}(2,130)=1.291, \mathrm{P}=.279$. This suggest that the years of teaching experiences failed to exert any influence on EFL teachers' knowledge of teaching English.

Table 6. ANOVA Procedure for the Score of EFL Teachers' Knowledge of Teaching English Based on Their Years of Teaching Experiences.

\begin{tabular}{lllllll}
\hline & & Sum of Squares & Df & Mean Square & F & Sig. \\
\hline \multirow{2}{*}{ Knowledge } & Between groups & .253 & 2 & .127 & 1.291 & .279 \\
Total & Within groups & 12.759 & 130 & .098 & & \\
\hline
\end{tabular}

Significant at the level of $\mathrm{P}<.05$

\section{Discussion and Conclusion}

The results from the present study indicate that teaching skills are the most dominant element in EFL teachers' knowledge of teaching English compared with other elements such as subject matter knowledge, pedagogical reasoning \& decision making, contextual knowledge, and communication skills. This result revealed that the influence of EFL teachers' teaching skills on their knowledge of teaching English were at the high level.

These findings also showed that there is a significant influence of EFL teachers' teaching skills to their practices of teaching English on how they plan and implement their lesson. The evidence in this study highlight the importance of teaching skills to influence how the teachers' selecting learning activities, presenting language, ensuring students' understanding, organization and facilitation communication interaction, judgment of proper balance between fluency and accuracy, awareness of students' errors and proper treatment of errors. This is a positive phenomenon, in which teaching skills refers to those aspects of teaching and would be the core competency of an English teacher [16, 8, 17].

The findings also proved that there is no significant differences between the less experienced English teachers (1-4 years), the experienced English teachers (5-10 years), the most experienced English teachers (above 10 years) and their knowledge of teaching English. This finding is in contrast with the findings of some researchers. [23] stated that teachers who teach less than three years are ineffective, while they steadily improved at around five years. Moreover, [24] argued that unlike the less experienced or novice teachers, experienced teachers found to own a well-organized knowledge base [24, 25].

The findings highlight the importance of knowledge of teaching English among EFL teachers, since this knowledge 
of teaching English may influence what and how they will teach in the future. Besides, schools may take the benefits of the findings of this study to understand the needs of the teachers, and to provide a good context to build up teachers' knowledge as well as motivate the teachers to improve the standard of their teaching. Results from the survey also will help the government to provide better assistance to support the needs of EFL teachers to improve their professionalism. It need further research to investigate about the more other factors which contribute the success of teaching English.

\section{References}

[1] Smith \& Zeicher (2005). Studying Teacher Education (The Report of the AERA Panel on Research and Teacher education) American Educational Research Association. In The Adult ESL Classroom. In D. Freeman and J.C Richards (eds.) Teacher Learning in Language Teaching (pp. 197-216). Cambridge: Cambridge University Press.

[2] Jensen, R.A., \& Kiley, T.J. (2005). Teaching, Leading, and Learning in Pre K-8 Settings: Strategies for Success (2nd ed). Boston: Houghton Mifflin.

[3] Hill, H.C, et al., (2005). Effects of Teacher's Mathematical Knowledge for Teaching on Student Achievement. American Educational Research journal. 42 (2): 371-406.

[4] Akbari \& Moradkhani (2010). Iranian English Teachers' self-efficacy: Do Academic Degree and Experience make a difference?. Pazhuhesh-e Zabanha-ye Khareji, No. 56, Special Issue, English, Spring

[5] Ur, P. (1996). A Course in Language Teaching: Practice and theory. Cambridge: Cambridge University Press.

[6] Abdul Razaq Ahmad, Ahamad Rahim, A., \& Seman, A.A. (2013). Active Learning through History Subject towards Racial Unity in Malaysia. The Social Science, 8(1), 19-24.

[7] Jalal, F. Samani, M., Mae, C.C., Steverson, R., Ragate, B.A., \& Negara, D.S. (2009). Teacher Certification in Indonesia: A Strategy for Teacher Quality Improvement. Jakarta: Departement Pendidikan National.

[8] Shulman, L.S. (1987). Knowledge and Teaching: Foundations of the New Reform. Harvard.

[9] Pettis (2013). Developing Our Professional Competence: Some Reflections. In Richards \& Renandya (Eds). Methodology in Language Teaching: An Anthology of Current Practices (pp.393-395). Cambridge University Press.

[10] Shulman, L.S. (1986). Those Who Understand: Knowledge Growth in Teaching. Educational.

[11] Richards, J.C. (2001). Curriculum Development in language Teaching. Cambridge University Press.

[12] NCATE (2013). What Makes a Teacher Effective? Dotnetnuke, Corporation.

[13] Cooper (2006). Classroom Teaching Skills (8th ed.) Boston: Houghton Mifflin.

[14] Calderhead, J. (1981). A Psychological Approach to Research on Teachers' Classroom Decision Making. British Educational Research Journal 7: 51-57.
[15] Fenstermacher, G.D. (1986). Philosophy of Research on Teaching: three Aspects in M.C. Wittrock (Ed.), Handbook of Research on Teaching ( $3^{\text {rd }}$, pp. 37-49). New York: Macmillan.

[16] Richards, J.C. (1998). Beyond Training. Cambridge University Press.

[17] Kyriacou, Chris. (1991). Essential Teaching Skills. Basil Blackwell Ltd.

[18] Clark, C.M., \& P. L. Peterson. (1986). Teacher Thought Processes in Freeman and Richards (ed.) Teacher Learning in Language Teaching.

[19] Shavelson, R.J., \& Stern, P. (1981). Research on Teachers' Pedagogical Thoughts, Judgement and Behaviors. Review of Educational Research, 51, 455-98.

[20] Grossman. P.L. (1988). A Study Contrast: Sources of Pedagogical Content Knowledge for Secondary English. Stanford University. U.M.I

[21] Lampert, (1984). Teaching about Thinking \& Thinking about Teaching. Journal of Curriculum Studies. 16(10), 1-18.

[22] Owen, D.W. Hargie. (1986). The Handbook of Communication Skills. Rutledge.

[23] Hammond, D. (2000). Teacher Quality and Student Achievement. Educational Policy Analysis Archives, 8 (1) ISSN 1068-2341.

[24] Freeman, D., (1982). Redefining the Relationship Between Research and What Teachers Know. In K.M. Bailey \& D. Nunan (eds.). Voices from the language classroom: Qualitative research in second language classrooms (pp. 88-115). New York: Cambridge University press.

[25] Roberts, J. (1998). Language Teacher Education. London: Arnold.

[26] Lauder, A. (2008). The Status and function of English in Indonesia: A Review of Key factors. MAKARA, SOCIAL HUMANIORA, 12 (1), 9-20.

[27] M. Nur Mustafa. (2013). Professional Competency Differences among High School Teachers in Indonesia. International Education Studies. Canadian Center of Science and Education.

[28] Depdiknas RI. (2003). Law No. 20 year 2003 on the National Education System, Jakarta Depdiknas.

[29] Depdiknas RI. (2006). School Based Curriculum. Jakarta. Depdiknas.

[30] Thalal, M. (2010). New Insights into Teaching English Language to Indonesian Students. Unpublished paper.

[31] Yuwone, G. (2005). English Language Teaching in Decentralized Indonesia: Voices from the Less Privileged Schools. Paper presented at the AARE 2005 International Education Research Conference.

[32] Kirkpatrick, A. (2007). Teaching English Across Culture: What do English language Teacher Need to Know How to Teach English. EA Journal, 23(2), pp. 20-33.

[33] Pasassung, N. (2003). Teaching English in an "Acquisition Poor Environment": An Ethnographic example of a remote Indonesian EFL Classroom. A Thesis Submitted in Fulfillment of the Requirements for the Degree of Doctor of Philosophy. University of Sydney. 
[34] Lie, A. (2007). Education Policy and EFL Curriculum in Indonesia: Between the Commitment to Competence and the Quest for Higher Test Scores. Universitas Katolik Widya Mandala, Surabaya. TEFLIN Journal.

[35] Darjowidjojo, S. (2000). English Teaching in Indonesia. EA journal, 18(1), 22-30.

[36] Pardede,D. (2013). Tribunnews. Com (www.tribunnews.com/regional/2013/06/04/hasil-uji-kompete nsi-guru-uhs.hanya425).

[37] Herlinawati. (2011). The Effectiveness of Indonesian English Teachers Training programs in Improving Confidence and Motivation. International Journal of Instruction.

[38] Exley, B. (2004). Indonesian EFL Curricula: What Content Knowledge Demands do They Make of Australian Teachers? Performing Educational Research: Theories, Methods \&
Practices, p.363-374. Post Pressed, Flaxton.

[39] Marcellino, M. (2008). English Language Teaching in Indonesia: A Continuous Challenge in Education and Cultural Diversity. Universitas Katolik Atma Jaya, Jakarta

[40] Ministry of National Education (MONE) 2008. Act No 20 year 2003. Jakarta: Depdiknas.

[41] Wadham, B. Pudsey, J., \& Boyd, R. (2007). Culture and Education. French Forest, NSW: Pearson Education Australia.

[42] Murdoch, G. (1997). What Makes A Good English Language Teacher? In TESOL Arabia 1997. Third International Conference, Vol.11. Conference Proceedings Selected Papers, March. 96-108. 